\author{
Natalia Olszanecka \\ ORCID https://orcid.org/0000-0003-3601-8280 \\ Uniwersytet Mikołaja Kopernika w Toruniu
}

\title{
SOCIAL DIMENSION OF THE RUSSIAN ARMED FORCES REFORM
}

KEYWORDs: Russia, social problems, armed forces, military reform, dedovshchina

ABSTRACT: At the beginning of the 1990s the political and military global reality was radically transformed. It affected all spheres of socio-political life and was visible also in the armed forces. At the beginning of the second decade of the 21st century, the Russian armed forces were still one of the most troubling military mechanisms in the world. In 2007 the Minister of Defense Anatoly Serdyukov decided to implement a broad military reform, which included (besides organizational issues and modernization of military equipment) also social issues. The aim of this article is to analyze the second stage of the armed forces reform in Russia (2010-2015) that entailed improvement of material status and livelihood of soldiers. The main research method used in this article was content analysis. A particularly important source was the study conducted by Irina Surkowa and articles published in Russian newspapers. The analysis showed that the reforms initiated by Serdyukov considerably improved the living conditions of the soldiers.

At the beginning of the 1990s the political and military global reality was radically transformed. For Russia this new reality was marked by a multidimensional crisis, which accompanied its political transformation. It affected all spheres of sociopolitical life and was visible also in the armed forces. An increasing budget deficit and rising inflation resulted in slashing defense spending. Moreover, the change in geopolitical situation and the need to ensure internal and external security necessitated in the government carrying out a comprehensive armed forces reform. However, it was delayed due to opposition of the military bureaucracy in the ministries of Pavel Grachev and Ivan Rodionov and a lack of a focused presidential leadership (Korotkevich 2004, 19ff.). Yeltsin's administration failed to: adapt Russian armed forces structure to the hazards of the modern world, eliminate social, technical and technological problems and solve conflicts in the chain of command (Odom 1998, 43ff.; Barabanow, Glantz 2011, 10ff.).

In 2000 Vladimir Putin took office. Until the end of his second term, his administration achieved several successes in armed forces reform. Among them were: raising defense spending, reorganizing military agencies, flattening bureaucratic hierarchy, establishing units in constant full operational readiness and partially implementing contract service in the army (de Haas 2011, 10f.). However, 
the following were not completed: reform of the military-industrial complex, increase funding of research and development $(\mathrm{R} \& \mathrm{D})$, increase coordination and discipline in military planning (Tellis, Wills 2005, 175ff.). Unresolved still were problems with conscription and financial security of soldiers (Korotkevich 2004, 19ff.), low prestige and negative phenomena in the army.

In 2008 a wide reform of the military was began by the then Minister of Defense of Russia Anatoliy Serdyukov. It had three stages and is set to end in 2020. The first stage (2008-2010) entailed introducing structural changes in the Russian armed forces. This phase is regarded as completed with success. The aim of this article is to analyze the second stage of the armed forces reform in Russia (2010-2015) that entailed improvement of material status and livelihood of soldiers. Firstly, the paper presents the greatest challenges that Russian soldiers and their families faced in terms of material needs and, secondly, the steps that were taken to eliminate them in the years 2010-2015. The main research problem is an evaluation if the taken measures were successful.

\section{Main problem areas until 2007}

For many years, it was widely believed that the social situation of the Russian army is appalling and pathologies are rampant, including the ubiquitous dedovshchina (the brutalization of new conscripts by those with greater seniority in service), crime, corruption and material problems of soldiers. It was connected with low prestige of the soldier profession, avoiding conscription to the army by young people, deprofessionalization, demographic and nationality problems, etc.

According to research conducted by Irina Surkova in the years 2006-2007, among the main problems related to the living needs of Russian soldiers were: housing problems, low salaries, bad living conditions, dedovshchina and criminalization of life in the army. Analyzing the statistical data from that period, it is possible to state that 36 percent of military families lived below the poverty line, 52 percent of officers needed to take on a second job, out of whom 29 percent had permanent employment elsewhere (as security guards and caretakers in security firms). In almost one of five military families the main source of family income were the spouse's wages or wages of another family member.

Surkova conducted her research on a sample of nearly 500 soldiers based in 5 military installations. According to her research outcome, military workers indicated housing problems as the main problem related to living needs. The lack of housing for soldiers was a serious concern. A guarantee of free housing was one of key elements that were to entice young people to serve in the army. The data shows that 55.7 percent of soldiers entered the army ranks hoping to receive an apartment 


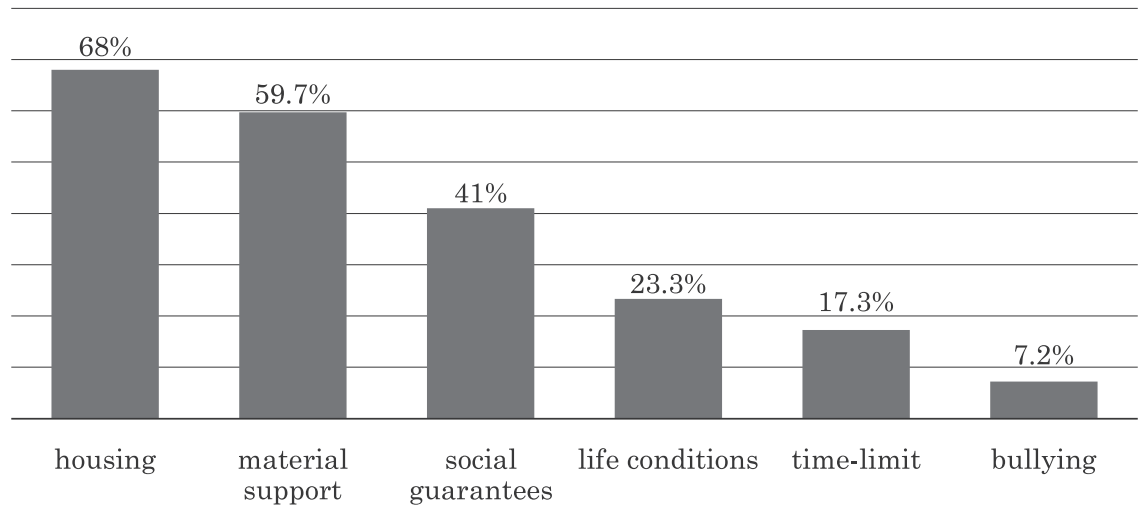

Chart 1. Social problems of Russian soldiers in 2006-2007 Source: Surkova 2010

in the nearest future. However only 10.8 percent of the respondents claimed they had no problems in obtaining housing (Surkova 2010, 6ff.).

It is worth to emphasize that the right to a home is enshrined in the Constitution of the Russian Federation (chapter II, article 40). This can entail providing a hotel room, rental accommodation or any other type of quarters. Housing should have basic necessities to create normal living conditions for the workers. One of important solutions of this problem were subsidies for buying apartments or homes. This program began as early as in 1998. Subsidies came from the federal budget and covered 80 percent of the costs. Another issue directly connected with access to military apartments were living conditions. They were mentioned by military personnel as the fourth most important problems in terms of living needs. This pertained mainly to the state of military quarters. Often they were temporary barracks, deemed unfit for habitation by experts from sanitary services (Ibidem).

The second most important issue were salaries. As it was mentioned before, most of military families lived on the verge of poverty since the 1990s. In 2003 an average monthly income in a military family in Saratov was 2559.75 Russian rubles. The basic living expenses were estimated at 1930 rubles. In the years 2006-2007 the salaries of soldiers ranged from 1000 to 35000 rubles. The average salary was then 8049 rubles. This amount was, for example, twice the average monthly pay in the Ural Mountains (the region of Yekaterinburg - 3862 rubles, Tyumen - 3956 rubles) or in Saratov (3537 rubles). Thus, the soldiers' salaries increased by a factor of two or three in comparison to 2003. However, during the same the prices of food and media also increased. Apart from base salary, military personnel was entitled to various benefits, e.g. relocation benefit; nutrition; housing and covering expenditure relating to rental; healthcare and medical aid; mandatory personal insurance; travels; additional remuneration for military service in conditions 
of state of emergency or military confrontation. However, it was stressed that the salary and benefits did not match the physical and psychological hardship of the soldiers (ibidem).

The problems that were mentioned by 7 percent of military personnel and about 50 percent of Russian citizens are manifestations of dedovshchina, bullying and criminalization of military life. Minister Sergei Ivanov on multiple occasions denounced all suggestions that the army is highly criminalized. He emphasized that, according to the statistics, the army compared to the general society is doing fairly well. S. Ivanov suggested also that dedovshchina is a more formalized (and not more brutal) version of hierarchical relations that exist in all Russian institutions and social groups. Some experts even claim that this practice of harassment is unavoidable in the army because it is an integral trait of the society (Moshkin 2006; Pavlyutkina 2006).

One of the manifestations of dedovshchina is bullying of young conscripts. A popular practice was the so-called 'one hundred days', which consisted of daily extortion of a given amount of money or cigarettes from a conscript. Sometimes bullying took more extreme forms, which were widely covered by the Russian media and made public by the Committee of Soldiers' Mothers of Russia. It is a fact that the culprits very rarely were tried before court since witnesses and victims were afraid of repressive measures (Kostyukovskiy 2007; Marakulin 2007).

According to official reports in 2007 there was a decline in criminal activity in the Russian armed forces. However this is attributed mainly to the reduction of the army size. The number of crimes committed in 2006 (in comparison to 2005) was nonetheless actually reduced. The number of homicides decreased by 20 percent and grave physical injuries by 25 percent. The number of deaths resulting from the practice of dedovshchina dropped by half. The data from the Ministry of Defense of the Russian Federation pointed also to a decrease in the number of deaths among soldiers - to just above 1200 persons in 2006. However, if we examine the causes of deaths, the situation looks worrying: 29 percent were suicides and 19 percent were homicides. The suicide rate is very high at 30 per 100 thousand soldiers (for comparison, in the British army it is 10 per 100 thousand soldiers). At the beginning of 2007 criminal activity also dropped noticeably. The widely publicized case of mutilation of conscript Andrey Sychev in early 2006 acted as a catalyst for detection of similar incidents in the Russian army (Taratuta 2007; Panyushkin 2007).

Much less optimistic data was published by the New York Times. According to these statistics, at least 292 soldiers were killed as a result of dedovshchina (the official number of victims is 16). Until August of that year 3500 reports of abuse in the Russian army were registered (Russia army suicides cause alarm 2008).

One of the most serious problems that directly affected the living conditions of the Russian soldiers were abuses of power. It mainly consisted of abusing lower- 
ranking soldiers by higher-ranking officers. Most commonly, conscript soldiers were hired by their superiors to work outside the military base, to work as unskilled labor in private companies and even to become private servants. Sometimes it was the only way of improving the material status of the officers. At the end of the 1990s an average salary in the armed forces did not cover basic living expenses and salaries were not paid on time. Being aware of this increasing problem already in October 2005 Minister Sergei Ivanov issued a decree penalizing "supervisors of all ranks who send soldiers to work outside military installations". This resulted in a media witch-hunt for all officers who infringed upon the new laws. As a consequence a few dozen people were tried before court (60 tys. rubley 2006$)^{1}$.

\section{Armed forces reform and living conditions of soldiers}

Serdyukov's reform solved many problems related to living conditions that the soldiers had. One of the actions taken was to reduce the number of soldiers by 1 million. However, proposed severe cuts in the officer corps were eventually reduced. Initially the planned reduction entailed 185 thousand officers. This number was subsequently limited to 115 thousand. This decision eased the strain on the defense budget, increased professionalization of Russian soldiers and helped to solve issues such as housing problems. Moreover, defense spending was also increased. Armed forces reform included selling army assets that did not generate revenue. This included land and equipment that could be used by civil businesses. Thanks to these measures, the defense budget could receive additional income.

In 2010 defense budget was 42.5 billion dollars, which constituted and increase of 3.5 percent year on year. Defense spending in 2010 was about 2.84 percent of the Russian GDP (Russian Federation Fiscal Year, 2010). In December 2020 President Medvedev stated that defense spending in the years 2011-2020 would stay at the level of 2.8 percent of GDP, which would allow equipping the armed forces with new technologies and solving all problems related to living conditions of the Russian soldiers. However, fulfilling all points of GPV-2020 (State Armaments Program 2020) required the expenditure to grow to 54 billion dollars in 2011 and 72 billion in 2013.

The problems with living conditions (especially with regard to criminalization of life in the military) were also alleviated by the decision to limit the number of conscripts. Some of social problems that are typical for conscript armies are rare in professional armies. In armies whose recruits join under pressure and involuntarily

${ }^{1}$ It must be said that the new laws were still not uniformly implemented. The prosecutor's office wanted a penalty of 3 years of imprisonment for Colonel Nasim Nazarov. In the end however he paid a fine and was sentenced to a one-year suspension because the injured soldier was "not forced to work: he was just sent to the premises of a private businessman to mind the bulldozer which belonged to his team". 
issues such as lack of military discipline and negative phenomena like alcohol and drug abuse as well as dedovshchina are rampant. These negative phenomena affect the morale of the armed forces and its social standing. Conscription also invites corruption - many young people prefer to bribe doctors or members of the recruiting committee in order to be disqualified from military service. On the other hand, professional army is more disciplined and uniform thanks to a spirit of solidarity (Jehn, Selden 2015). In the mid-2011 there were 180 thousand contract soldiers in the Russian armed forces. President Dmitry Medvedev decided to increase that number to 425 thousand in 2017 since Russia has serious problem with demographic changes and general health of the society. Demographic imbalance and fast ageing of the population led to a situation in which the number of recruits is inadequate (Felgenhauer 2010). As early as in 2013 subsequent actions of the Ministry of Defense of Russia were taken to increase the share of contract soldiers. New Minister Sergey Shoygu made claims that Russia will never completely abandon conscription. Enticing young people to enter professional service became a priority. Russia budgeted 51.8 billion rubles for this purpose. This money was to be spent on soldiers' salaries and on building housing. It was assumed that each year 50 thousand young men will enter service so that by 2017 the number of professional soldiers was to reach 425 thousand. Yet, the program was so popular that Shoygu decided to increase the number of professional soldiers to 499 thousand in 2017. In 2015 for the first time the number of professional soldiers was greater than the number of conscripts (McDermott 2014).

The remaining actions that were taken in view of improving the living conditions of soldiers in the years 2010-2015 included:

\section{a) solving housing problems}

In 2011 only $1 / 3$ of the officers obtained apartments they were entitled to due to their service. In December 2012 - 15 thousand soldiers and military personnel were on housing waiting list (in 2008 it was 160 thousand). Minister Shoygu allocated large amounts of money to solve problems related to living conditions of soldiers, because he wanted to entice young people to enter into contract service (Barabanow, Glantz 2011). According to Minister of Defense the waiting queue for housing was decreased by a factor of 2.8. In 201627 thousand military personnel obtained temporary housing and almost 20 thousand were given permanent housing. A popular form of support was a subsidized combination of a mortgage loan and an investment product, thanks to which 14 thousand military personnel bought houses (Today we are stronger 2016).

\section{b) salary increase}

Also in the sphere of remuneration the situation improved dramatically. Russian Vice Minister of Defense Tatiana Shevtsova informed at the end of January 2014 that 
the salary of a contract soldier in the rank of private was around 28 thousand rubles, which according to the then conversion rate was equal to 2.8 thousand of Polish zlotys. The salaries of Russian officers were even higher. A sergeant commanding a unit earned 39 thousand rubles and a junior officer in the rank of lieutenant earned about 59 thousand rubles (Kular 2015).

\section{c) decreaing problems connected to criminalization and dedovshchina}

Cases of dedovshchina continued to be present. Physical abuse of young conscripts resulted in going AWOL, psychic breakdowns, suicide and homicide ${ }^{2}$. Investigating committee of the Russian Federation stated in February 2015 that the number of cases related to dedovshchina decreased by 16 percent. The Committee of Soldiers' Mothers of Russia confirmed the decrease in the number of incidents, stating however that the organization receives about 400 complaints each year (Istinnoye litso sovremennoy rossiyskoy armii i yeye ottsov-komandirov 2017).

\section{d) increasing military pensions}

Salaries of military personnel and military pensions by 2012 were increased by a factor of 2 or 3 in comparison to 2007. The Russian army was well-disposed to become one of the best employers in the state. Moreover 250 billion rubles were set aside for building housing for military pensioners.

\section{Conclusions}

It took the Russian administration nearly 20 years to take action to improve the conditions in the Russian army. Among the most pressing problems in terms of living conditions of the soldiers were issues relating to housing, low salaries and inadequate social guarantees. An important problem were negative phenomena such as dedovshchina, alcohol and drug abuse as well as corruption. It is difficult to assess their reach since there are no objective studies on this subject. Russian sources and foreign analyses present different data. Undoubtedly, the reform initiated by Serdyukov and continued since 2012 by Shoygu considerably improved the living conditions of soldiers. Among the most important actions taken by the Ministry was reducing the total number of soldiers, increasing the number of professional soldiers and increasing defense spending. It allowed to almost completely eradicate housing problems of military personnel. Their salaries still do not compare to NATO states soldiers' earnings, but the Russian armed forces became one

${ }^{2}$ In 2012 in the Chelyabinsk region Ruslan Aiderkhanov was raped and tortured to death by other soldiers. The only witness who wanted to testify against the alleged perpetrators, Danil Chalkin, was later found dead in the military base. 
of the most sought employers in the state. Currently the reform is in the third stage of realization - obtaining new military equipment.

Until recently, in the Western countries there was a stereotypical image of a Russian soldier - the proverbial Vanya with a "pepesha" submachine gun and felt boots, a sack on his back, a piece of string around his waist, who is dirty, drunk and malnourished. The current reform changed this image. It was noticed that the Russian army started to catch up not only in terms of armaments. The Ministry of Defense also put emphasis on human resources. A Russian soldier is to be a professional soldier, well-trained, wearing a modern uniform, bearing modern arms and disciplined. The first step towards that goal was the improvement of the soldiers' living conditions so that military service became an appealing career choice.

\section{References}

60 tys. rubley (2006), 60 tys. rubley. In: Moskovskiy Komsomolets. 3 February.

Barabanow, M./Glantz, D. (2011), Rusia's New Army. Moscow.

HAAs, M. de (2011), Russia's Military Reforms Victory after Twenty Years of Failure? In: Clingendael Papers. 5, 10-11.

Felgenhauer, P. (2010), Rearmament Declared the Main Issue in Russian Military Reform. In: Eurasia Daily Monitor. 7/122. URL: www.jamestown.org/single/?no_cache=1\&tx_ttnews\%5Btt news $\% 5 \mathrm{D}=36521$.

Istinnoye litso... (2017), Istinnoye litso sovremennoy rossiyskoy armii i yeye ottsov-komandirov. URL: http://sprotyv.info/ru/news/kiev/istinnoe-lico-sovremennoy-rossiyskoy-armii-i-ee-otcov-komandirov.

JeHN, S./SELDEN, Z. (2015), The End of Conscription in Europe? URL: http://www.rand.org/content/ dam/rand/pubs/monographs/MG265/images/webS0228.pdf.

Korotkevich, V. I. (2004), Istoriya sovremennoy Rossii 1991-2003. St. Petersburg.

KostyukovskiY, A. (2007), Bol'nogo soldata prizvali po zakonu. In: Gazet. 16 January.

KULAR, P. (2015), Reforma sił zbrojnych Rosji. URL: https:/www.mpolska24.pl/post/9214/reformasil-zbrojnych-rosji.

MARAKULIN, D. (2007), Dembelya sobrali uliki na sebya. In: Kommersant. 8 February.

McDermott, R. (2014), Russia's Glacial Progress Toward a Professional Army. In: Eurasia Daily Monitor. 11/201.URL: http://www.jamestown.org/programs/edm/single/?tx_ttnews[tt_news]=43 073\&cHash=bd8d0cbb41f630bcd9eac0ef312957e5\#.Vo4tPVKKJCA.

Moshkin, M. (2006), Dovol'no zakonoposlushnyy chelovek s ruzh'yem. In: Gazeta. 29 March.

Odom, W. E. (1998), The Collapse of the Soviet Military. In: New Haven. 43, 369.

Panyushikin, V. (2007), Mirnyy god. In: Vedomosti. 17 January.

Pavlyutkina, I. (2006), Kak zashchitit' cheloveka s ruzhyem. In: Krasnaya Zvezda. 17 February.

Russia army... (2008) Russia army suicides cause alarm. URL: http://news.bbc.co.uk/2/hi/europe/7425694.stm.

Russian Federation... (2010), Russian Federation Fiscal Year. In: U.N. Office of Disarmament Affairs. URL: http://disarmament.un.org/Milex.nsf.

Surkova, I. (2010), Social Problems in the Russian Army within the Framework of Social Work. In: Journal of Comparative Social Work. 2, 6-9.

TARatuta, Y. (2007), Otlichniki statisticheskoy podgotovki. In: Kommersant. 26 January.

TelLis, A. J./Wills, M. (2005), Military modernization in an Era of Uncertainty. Seattle.

Today... (2016), Today we are stronger. URL: http://russiandefpolicy.blog/category/military-housing. 